\title{
A suitable method to detect potential fraud of bringing Malayan box turtle (Cuora amboinensis) meat into the food chain
}

\begin{abstract}
Malayan box turtle (Cuora amboinensis) has been a wildlife-protected vulnerable turtle species in Malaysia since 2005. However, because of its purported usage in traditional medicine, tonic foods and feeds, clandestine black market trade is rampant. Several polymerase chain reaction (PCR) assays for the taxonomic detection and classification of turtle species have been proposed. These assays are based on long-length target amplicons which are assumed to break down under compromised states and, hence, might not be suitable for the forensic tracing and tracking of turtle trafficking. For the first time this paper develops a very short-amplicon-length PCR assay (120 bp) for the detection of Malayan box turtle meat in raw, processed and mixed matrices, and experimental evidence is produced that such an assay is not only more stable and reliable but also more sensitive than those previously published. We checked the assay specificity against 20 different species and no cross-species detection was observed. The possibility of any false-negative detection was eliminated by a universal endogenous control for eukaryotes. The assay detection limit was $0.0001 \mathrm{ng}$ of box turtle DNA from pure meat and $0.01 \%$ turtle meat in binary and ternary admixtures and commercial meatballs. Superior target stability and sensitivity under extreme treatments of boiling, autoclaving and microwave cooking suggested that this newly developed assay would be suitable for any forensic and/or archaeological identification of Malayan box turtle species, even in severely degraded specimens. Further, in silico studies indicated that the assay has the potential to be used as a universal probe for the detection of nine Cuora species, all of which are critically endangered.
\end{abstract}

Keywords: Malayan box turtle; Endogenous control; Forensic and archaeological identification; Short-amplicon-length PCR assay; Wildlife protection 